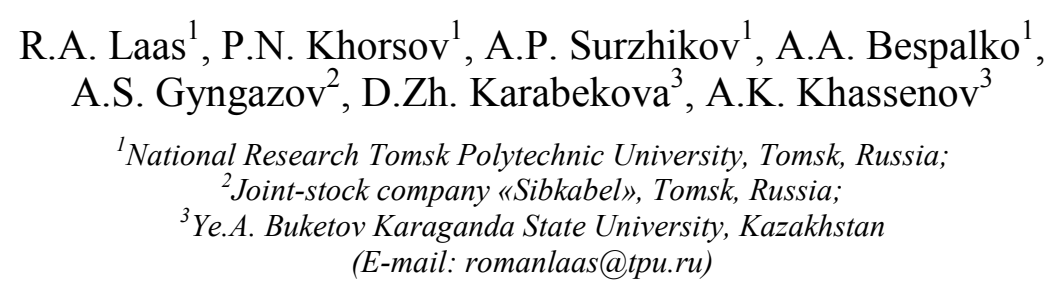

\title{
Two-Dimensional Ray Mathematical Model of Mechanoelectric Transformations Method for Location of Macrodefects Identification in Solid Dielectric Structures
}

\begin{abstract}
Method of mechanoelectric transformations can be applied to determine both horizontal position and the depth of a defect in solid nonconductor samples. The method is based on phenomenon of electromagnetic emission in sources of mechanoelectric transformations, such as cracks, voids and impurities of sample structure. It has been shown that method can be used to evaluate integrated stress-strain state of solid dielectric materials. The method is also capable of finding defects is the sample volume, but the robust methodology has to be developed. To develop a methodology of the proper scanning process the experimental setup was created. This work represents ray model of this setup. The model allows us to research pulse characteristics of the response signal considering a variety of excitation signal parameters, defect locations and depths. The model includes dimensions of real sample. Pulse characteristics for response signals of single-period excitation waves with $100 \mathrm{kHz}, 300 \mathrm{kHz}$, and $600 \mathrm{kHz}$ frequencies were obtained. It is shown that increasing the frequency of excitation increases the accuracy of estimating the depth of macrodefects. Time-response characteristics of the signal are most informative.
\end{abstract}

Keywords: mechanoelectric transformations, acoustic control, nondestructive testing, mathematical model, solid dielectric structures, defectoscopy, response signal, excitation wave.

\section{Introduction}

Acoustic methods are widely used to search and control macrodefects in structures. Most of them are based on pulsed excitation of the test object by the acoustic wave and the following study of response characteristics associated with a macrodefect [1-5].

Numerous acoustic methods of searching defect coordinates have been developed [6-8].

The disadvantage of these methods is the requirement of reliable acoustic contact between the receiver and the object of control. The response signal may be distorted due to heterogeneity of the surface mechanical properties of the sample, which leads to instability in the transient characteristic of the contact.

However, there are methods, which do not require reliable surface contact, for example, the method of mechanoelectric transformations (MET). It is found that in solid dielectric under certain conditions like stress electromagnetic emission appears on the surfaces of cracks and defects [9]. Double electric layers at the interfaces of dissimilar materials are sources of MET, as well as natural piezoelectric inclusions (quartz sand in concrete, for example). The method of electromagnetic emission can be informative to determine stress-strain state of materials, but the method is considered passive. Further investigations have shown that it is possible to induce an electromagnetic response by acoustic excitation of the sample [10-13]. Studies indicate that the MET method is suitable for defectoscopy of solid dielectrics. First, there were investigations on registration of response signals for samples made of epoxy resin with addition of sand, which contained lots of quartz [14]. To determine whether results of studies are redundant, statistic methods were utilized, for instance, those based on Students t-distribution [15]. These methods utilize integrated response characteristics to evaluate bulk and surface defects [16]. The response signal received from the surface area above defect is distinguishable from those signals received from areas without defects since correlation drops dramatically in «defected» areas.

During ultrasonic testing, acoustic energy is being transferred to an electric signal in a localized acoustic transducer. Unlike that, transducers in MET method are located in the sample itself, so that the response signal is the superposition of signals from all the MET sources. As a result, a response signal is being received right after excitation and clearly carries no information about defects whatsoever. The excitation wave than reaches the defect and reflects back to the surface, creating the useful response signal that sums up with the parasitic one. Later on, the wave reflected from further boundaries if the sample also contributed to the integrated signal. 
It is also possible to utilize the reverberation effect to enhance the MET method. The main advantage of reverberation is the repeated intersections of the excitation zones of inhomogeneities by acoustic waves, that is displayed in response parameters. The reverberation makes it possible to accumulate distortions of wavefronts $[17,18]$.

The aim of this work is to evaluate the most suitable parameters of excitation and response signals to localize the defect.

\section{Methods and materials}

A new method of nondestructive testing has been developed in Tomsk Polytechnic University - method of mechanoelectric transformations (MET). Acoustic impulse of a given form excites dielectric sample. The excitation wave interferes with MET sources, which partially transfer acoustic energy to weak electromagnetic field. The capacitance sensor located close to the surface then transforms electromagnetic signal to current, which is then registered. Sources of MET include double electric layers at the interfaces of dissimilar materials and natural piezoelectric inclusions (quartz sand in concrete, for example). The main advantage of MET method over other acoustic methods is that MET method does not require reliable surface contact. This method can require no physical contact with a sample at all if laser beam is used as an excitation source [19].

Studies indicate that the MET method is suitable for defectoscopy of solid dielectrics.

During ultrasonic testing, acoustic energy is being transferred to an electric signal in a localized acoustic transducer. Unlike that, transducers in MET method are located in the sample itself, so that the response signal is the superposition of signals from all the MET sources. As a result, a response signal is being received right after excitation and clearly carries no information about defects whatsoever. The excitation wave than reaches the defect and reflects back to the surface, creating the useful response signal that sums up with the parasitic one. Later on, the wave reflected from further boundaries if the sample also contributed to the integrated signal.

To describe received electric signal from sample with distant MET sources ray mathematical model was developed [20].

The full biasing current $I$ over the segment of the detector is determined as following:

$$
I=\frac{Q}{S_{s}} \cdot \iint_{s_{s} s_{r}}\left\{\frac{d h}{d t} \cdot\left[\frac{1}{r^{3}} \cdot\left(\frac{3 \cdot H^{2}}{r^{2}}-1\right)\right]-\frac{d H}{d t} \cdot\left[\frac{3 \cdot h \cdot H}{r^{5}} \cdot\left(\frac{5 \cdot H^{2}}{r^{2}}-3\right)\right]\right\} \cdot d s_{s} \cdot d s_{r}
$$

$Q$ - is a bound charge of a single MET source; $S_{u}$ - is a square of a MET source; $h$ ) - is a width of a source $H$ - is a distance between MET source and the receiver.; $r(t)$ - is the length of the radius vector between the element of MET source and the element or receiver surface, considering reflections from boundaries of the sample.; $d s_{r}$ - elementary surface of the reciever; $d s_{s}$ - the element of surface area of MET source. Time indexes for $H, h$ and $r$ are left out.

Derivatives with respect to $h$ and $H$ are obtained from the equation for longitudal deformation $\delta l$ and its connection to mechanical normal stress $\sigma$ in elastic area.

Since the mechanical stress is not uniform in space, when calculating the deformation between two points, it is necessary to summarize the instantaneous elementary deformations, within which the mechanical stress can be considered unchanged. When calculating the strain rate across the width of the probe, the instantaneous mechanical stress can be considered constant due to the small value of $h$ and the expression for the vertical component of the derivative $h$ with respect to time has the form:

$$
\frac{d h}{d t}=k \cdot \sigma_{0} \cdot \frac{\frac{d F}{d t}\left(\mathrm{t}-\frac{|\vec{r}|}{v}\right) \cdot \mathrm{r}_{h z} \cdot h}{E^{2} \cdot\left|\overrightarrow{r_{h}}\right|}
$$

where $k$ - is the coefficient having a length dimension equal to the distance from the center of the spherical wave to the region of tension formation $\sigma_{0}$, which is equal, in a first approximation, to the ratio of the impact force to the contact area of the spherical surface of the excitation source with the sample; $\vec{r}$ - radius vector from the region of impact formation to a given point, taking into account reflections from the control object boundaries; $\left|\vec{r}_{h}\right|$ — the radius vector module from the point of impact to the given point of the MET source, $r_{h z}$ - is the projection of the specified radius vector on the vertical axis; $F(t-r / v)$ - equation of the excitation wave; $v-$ is the speed of sound in control object. 
When calculating the expression for the vertical component of the derivative with respect to $\mathrm{H}$, it is necessary to take into account the heterogeneity of the mechanical stress, therefore, it has the following form

$$
\frac{d H}{d t}=\frac{k \cdot \sigma_{0}}{E} \cdot \int_{0}^{H} \frac{\frac{d F}{d t}\left(\mathrm{t}-\frac{\left|\overrightarrow{r_{z}}\right|}{v}\right) \cdot \mathrm{r}_{z z}}{\left|\overrightarrow{r_{z}}\right|^{2}} \cdot d z
$$

where $r_{z z}$ - is the vertical component of $\vec{r}_{z},\left|\vec{r}_{z}\right|-$ is the radius vector module from the point of impact to the point of the given line connecting the point on the MEP source with the point on the receiver plate. The vertical component of the induction vector is calculated along this line.

where is the vertical component, is the radius vector module from the point of impact to the point of the given line connecting the point on the MEP source with the point on the receiver plate. The vertical component of the induction vector is calculated along this line.

As can be seen from expression above for the bias current, the response signal consists of two components. One component is associated with a change in time of the width of the MET source, (component $h$ ); the other component - with a change in the distance between the surface elements of the MET source and the signal receiver (component $\mathrm{H}$ ). From this expression it follows that each of these components can change its sign at certain angles between the vertical axis and the direction of the radius vector from the MET source to the receiver surface element. Therefore, the total response signal can be either a result of either arithmetic summation of the two components, or subtraction. Moreover, depending on the size and position of the surfaces of the MET source and the receiver, we can get a common signal as the sum of elementary responses, where not all components have the same sign.

In general, the described mathematical model shows that with a uniform distribution of the MET sources over the sample, those sources located near the signal receiver make the greatest contribution to the electrical response. Nevertheless, under certain conditions of the distribution of MET sources, the electrical response, which in this case can be called parasitic, begins to form almost without delay at the moment of excitation of the sample. After the acoustic wave reaches the surface of the defect, the response reflected from the microdefect of the wave begins to mix with the already existing response. Over time, acoustic waves reflected from the boundaries of the sample begin to influence the response.

To identify criteria of the defects, which can be found and assessed with MET method the experimental setup was created [21, 22]. Figure 1 shows the scheme of the setup.

A coordinatograph allows positioning the sending-receipt unit (SRU) above the specific place of the sample surface. The SRU consists of piezoelectric transducer and differential capacitive probe. The transducer emits a series of acoustic impulses. The shape and length of each impulse is determined by concerns of specific experiment and controlled via special software. The measurement input of the probe is located several millimeters above the surface of the sample. It receives electric component of electro-magnetic signal, which consists of both noise and informative signal. The generation and digitizing device (GDD) is based on multifunction Data acquisition device NI USB-6356. The output of GDD is connected to the high-voltage amplifier (HA) to amplify the signal before it comes to transducer. Multiple excitations are used to improve signal/noise ratio. Up to 256 measurements are summed up and averaged.

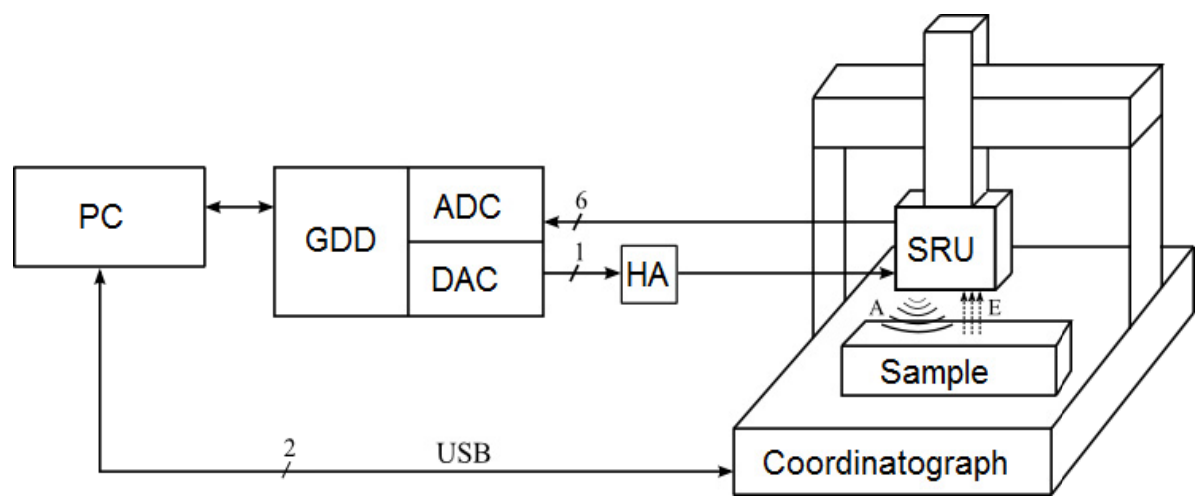

Figure 1. The experimental setup 
The setup was used to find out what kind of defects can be found with MET method.

The sample is a $100 \mathrm{~mm}$ thick concrete block with holes. Three holes have a diameter of $25 \mathrm{~mm}$ and depths 40,60 and $75 \mathrm{~mm}$.

It turned out that parasitic response signals are significantly affecting the response signal as a whole, so that it is difficult to choose optimal criteria for defects, which could be localized my MET method. For the same reason it is impossible to estimate suitable parameters of excitation waves right away.

The aim of this work is to show in a two-dimensional mathematical model that takes into account the ability to set the dimensions of the surfaces of the acoustic excitation source, macrodefect and the electrical response receiver, as well as the coordinates of the macrodefect, which excitation and response parameters are most effective for determining the coordinates of macrodefects in solid dielectrics.

Let us consider the following system: the source of the signal, receiver and defect, all located on plain surface (Figure 2). Here $a$ depicts the source; $b$ is the receiver; $c$ is the defect.

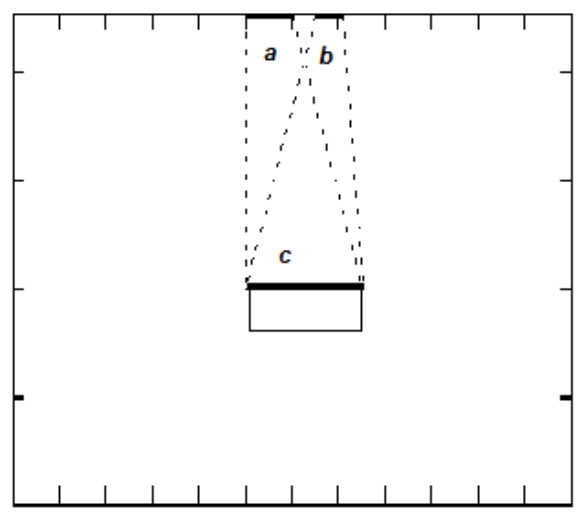

Figure 2. The scheme of experimental setup for studying electromagnetic responses when a sample is excited by an acoustic pulse of a given shape, where a is acoustic wave emitter; $\mathrm{b}$ is response signal receiver; $\mathrm{c}$ is the defect

Dashed lines portray rays which contribute to response signal formation. The model considers real dimensions of emitter, receiver, defects and their locations.

The length of emitter is $10 \mathrm{~mm}$, receivers is $6 \mathrm{~mm}$.

The source of the signal emits an acoustic excitation wave from each point of the surface of the emitter. The surface area is defined as a site with a linear size $\delta l=\delta t \cdot v$, where $v$ is the speed of sound in a concrete sample $(3200 \mathrm{~m} / \mathrm{s}) ; \delta t$ is the digitization interval.

The rays fall on the surface of the defect and are emitted into the region of the sample located in the immediate vicinity of the surface of the receiver. In this area, the level of the electromagnetic signal due to mechanoelectric transformations is the greatest.

The program sums up all the elementary responses from each ray emitted by the surface of the defect, which, in turn, is a superposition of rays from each point of the source of the acoustic signal.

The distances that each beam travels between the surface of the source and the macrodefect, as well as the surface of the macrodefect and receiver, were calculated. The response signals from each ray falling into the same time were summed. Each elementary response signal was calculated based on the sphericity of the acoustic wave, i.e. acoustic attenuation was taken into account inversely with distance. The delay time of the arrival of the rays to the receiver was also calculated to form the integral time dependence of the response. The resulting dependence is the impulse characteristic of the response signal for a given configuration of the emitter — defect — receiver system.

The program also calculated the impulse response characteristics when the source - receiver system was shifted relative to the defect, which simulated the scanning system for the sample.

Impulse characteristics were calculated for three depths of macrodefects: $25 \mathrm{~mm}, 40 \mathrm{~mm}$ and $60 \mathrm{~mm}$. In addition, the impulse response characteristics were calculated upon reflection of the excitation pulse from the bottom of the sample $(100 \mathrm{~mm})$.

Figure 3 shows the impulse response characteristics at a defect depth of $(25,40,60) \mathrm{mm}$ and with no defects respectively, under conditions when the sensor system is above the corresponding defect. The abscissa shows the relative distances that the acoustic rays travel. 


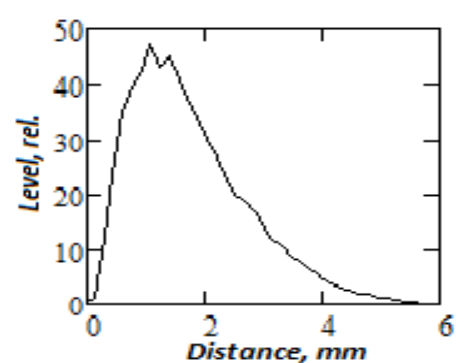

$\mathrm{a}$

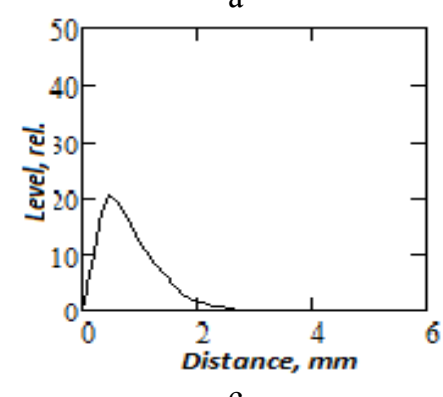

c

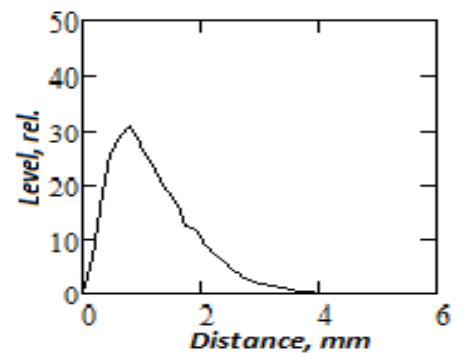

b

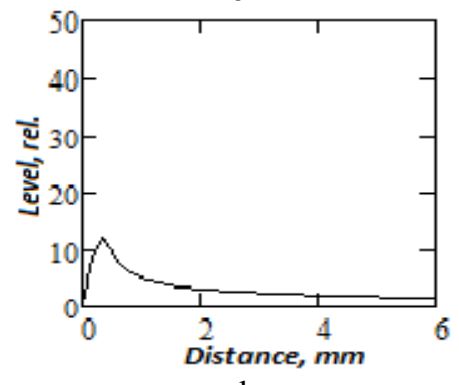

$\mathrm{d}$

Figure 3. Impulse response characteristics at a defect depth when the sensor system is above the corresponding defect, a) $25 \mathrm{~mm}$; b) $40 \mathrm{~mm}$; c) $60 \mathrm{~mm}$; d) without defect

As can be seen from the figures, for the given linear dimensions of the receiver, defect, and emitter, the range of distances that the rays of the acoustic excitation wave propagate at a defect depth of $25 \mathrm{~mm}$ is $6 \mathrm{~mm}$, at a depth of $40 \mathrm{~mm}-4 \mathrm{~mm}$, and at a depth of $60 \mathrm{~mm}-3 \mathrm{~mm}$. When the excitation signal is reflected from the bottom of the sample, the interval of the impulse response is $18 \mathrm{~mm}$. In this case, there is a strong surge of the signal at the beginning of the impulse response. Figure 4 shows the impulse response characteristics at a defect depth of $(25,40$, and 60$) \mathrm{mm}$ and with no defects underneath, respectively, under conditions when the sensor system is $10 \mathrm{~mm}$ shifted relative to the defect.

When the SRU is shifted relative to the defect, the response signal decreases and the impulse response expands. The range of distances for depths 25,40 and $60 \mathrm{~mm}$ is 12,8 , and $6 \mathrm{~mm}$, respectively.

Figure 5 shows the calculations of the maximum levels of the impulse response as a function of the bias and bias offset relative to the defect.

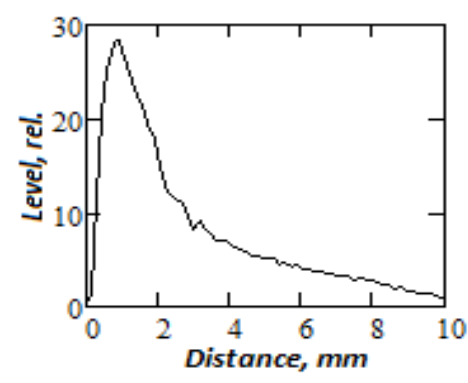

a

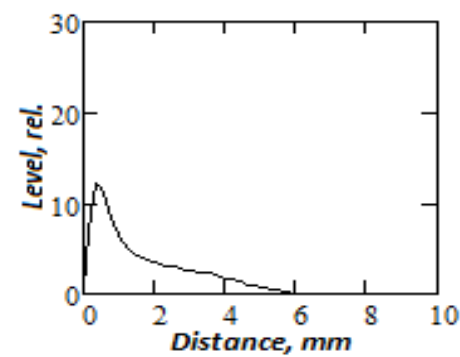

c

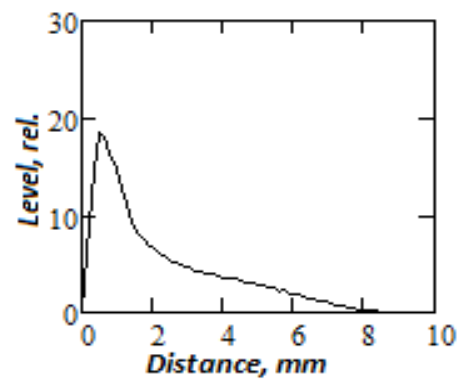

$\mathrm{b}$

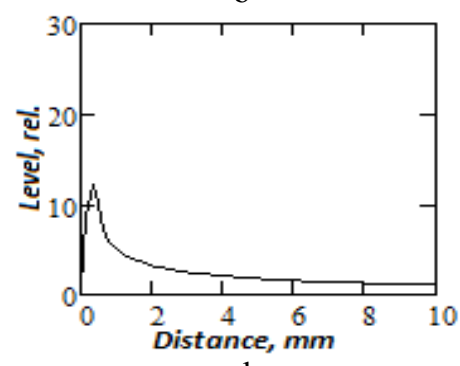

d

Figure 4. Impulse response characteristics when the sensor system is $10 \mathrm{~mm}$ shifted relative to the corresponding defects: a) $25 \mathrm{~mm}$; b) $40 \mathrm{~mm}$; c) $60 \mathrm{~mm}$; d) without defect 


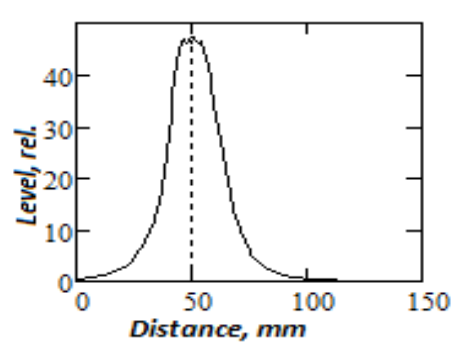

$\mathrm{a}$

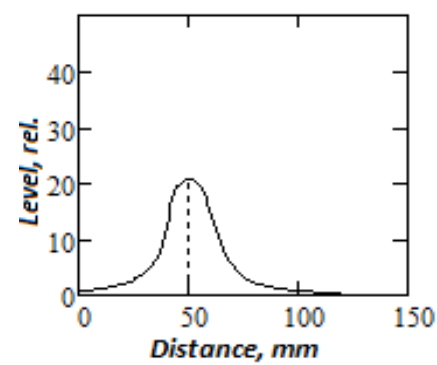

c

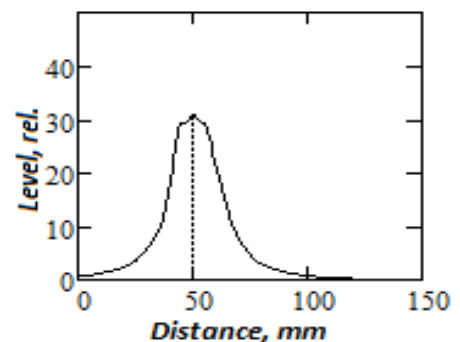

$\mathrm{b}$

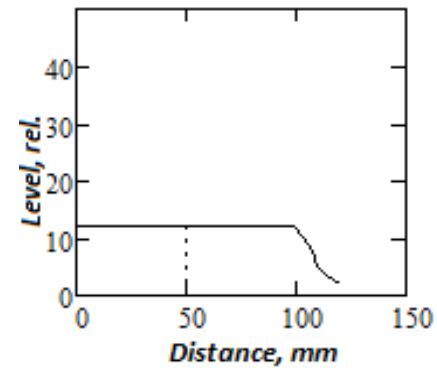

d

Figure 5. The maxima of the impulse response levels when the SRU is shifted relative to the corresponding defect depth: a) $25 \mathrm{~mm}$; b) $40 \mathrm{~mm}$; c) $60 \mathrm{~mm}$; d) without defect

As can be seen from Figure 5a, the maximum response when the acoustic excitation wave is reflected from the bottom is in fact independent of the displacement of the emitter and receiver assembly with respect to the defect. The vertical dashed line corresponds to the position of the SRU over the defect.

Studying the impulse characteristics, it is possible to calculate the responses when a pulse of a given shape is applied to the sample.

A rectangular radio pulse $u(t)$ was used as an excitation pulse in the model.

On the graphs of impulse responses along the ordinate axis, the intensities are plotted. Therefore, to obtain the response res $(t)$ when an acoustic pulse of a given shape is exposed to a sample, it is necessary to perform the convolution operation of its time dependence with the corresponding impulse response

$$
\operatorname{res}(\mathrm{t})=\sum_{\tau=0}^{t} \operatorname{imp}(\tau) \cdot u(t-\tau)
$$

where imp $(t)$ is the impulse response; $u(t)$ is the time dependence of the excitation pulse.

To solve the problem of determining the location of a macrodefect, as well as a possible assessment of its linear dimensions, we consider the responses at various frequencies and durations of the excitation pulse.

The presented responses are shown upon excitation of a sample with a rectangular radio pulse with a frequency of $100 \mathrm{kHz}$ for a period of 1 period in Figure 6.

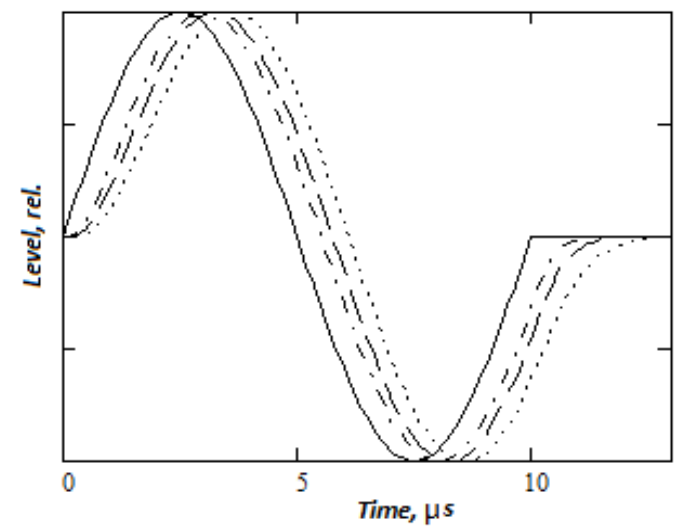

Figure 6: The responses when a sample was excited by a rectangular radio pulse with a frequency of $100 \mathrm{kHz}$ for a period of 1 period in the zones of defects with a depth of $25 \mathrm{~mm}$ (dots), $40 \mathrm{~mm}$

(dashed line), $60 \mathrm{~mm}$ (dashed-dotted line) and the shape of the excitation pulse (solid line). 
As follows from the figure, there is an increase in the duration of the response with a decrease in the depth of the defect. Figures 6 and 7 show that with increasing frequency, the degree of increase in duration increases.

As can be seen from all the figures, the waveforms of the responses are distorted to one degree or another with respect to the excitation pulse. It follows from a theory that the response duration is the sum of the duration of the initial pulse (in our case, the period of the corresponding frequency) and the duration of the characteristic with which the convolution is carried out. Therefore, the response duration is delayed with respect to the initial pulse [21-23].

The duration of the impulse response in the ray approximation of the propagation of an acoustic wave depends both on the depth of the defect, on the surface of which the excitation wave is reflected, and on its linear dimensions, as well as on the sum of the linear dimensions of the excitation source, receiver, and the gap between them.

Therefore, in general, the difference between the duration of the response and the duration of the excitation pulse is an indicator of the depth of the location of defects [24, 25].

The response signal is generated in a special way when the acoustic excitation wave is reflected from the bottom of the sample, which is due to the relatively large surface from which the acoustic excitation wave signal is reflected.

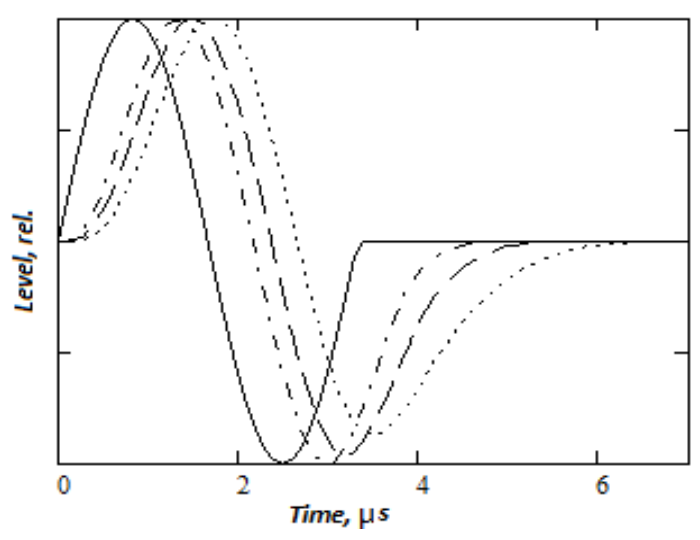

Figure 7. The responses when a sample was excited by a rectangular radio pulse with a frequency of $300 \mathrm{kHz}$ for a period of 1 period in the zones of defects with a depth of $25 \mathrm{~mm}$ (dots),

$40 \mathrm{~mm}$ (dashed line), $60 \mathrm{~mm}$ (dash-dotted line) and the shape of the excitation pulse (solid line)

Figure 7 and 8 show the given responses for frequencies of $300 \mathrm{kHz}$ and $600 \mathrm{kHz}$.

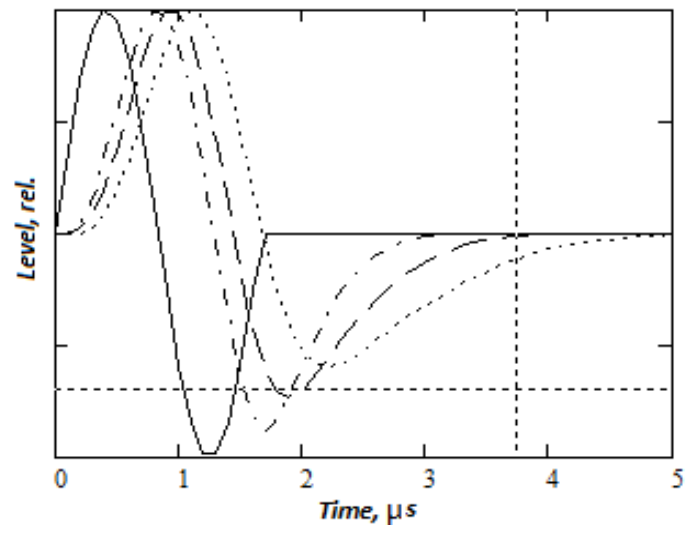

Figure 8 . The responses given when a sample was excited by a rectangular radio pulse with a frequency of $600 \mathrm{kHz}$ for a period of 1 period in the zones of defects with a depth of $25 \mathrm{~mm}$ (dots), $40 \mathrm{~mm}$ (dashed line), $60 \mathrm{~mm}$ (dashed-dotted line) and the shape of the excitation pulse (solid line)

Consider the response behavior in the spectral region. Figure 9 shows fragments of the amplitudefrequency characteristics (up to the first bend) of responses under the influence of a pulse with a frequency of $100 \mathrm{kHz}$ for defect depths $(25,40,60) \mathrm{mm}$, as well as the frequency response of the excitation pulse. 
As can be seen from the Figure 9, at a frequency of $100 \mathrm{kHz}$, all frequency response lines almost merge. At the same time, it is seen that the response frequency response when reflected from the bottom of the sample has a feature that is probably due to the manifestation of interference due to the superposition of acoustic waves whose path lengths exceed the coherence interval.

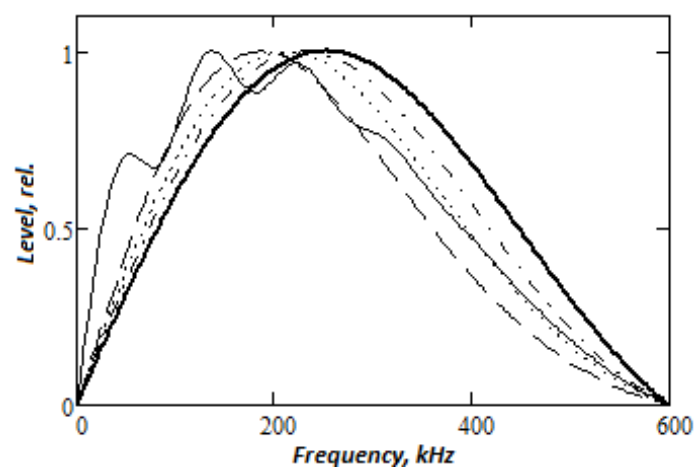

Figure 9. The amplitude-frequency characteristics of responses when reflected from defects at defect depths of $25 \mathrm{~mm}$ (dashed line), $40 \mathrm{~mm}$ (dots), $60 \mathrm{~mm}$ (dashed-dotted line), from the bottom of the sample (thin solid line) and the excitation pulse (thick solid line) at a frequency of $100 \mathrm{kHz}$

Figures 8 and 9 show the frequency response of the responses and the excitation pulse for the same depths for the frequencies $300 \mathrm{kHz}$ and $600 \mathrm{kHz}$.

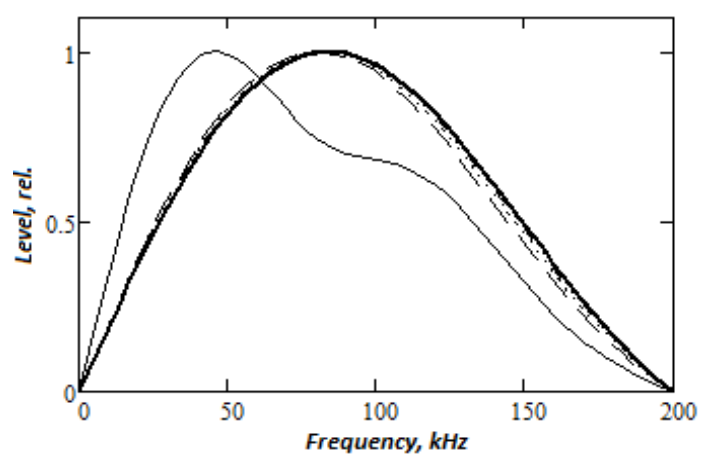

Figure 10. The amplitude-frequency characteristics of responses when reflected from defects at defect depths of $25 \mathrm{~mm}$ (dashed line), $40 \mathrm{~mm}$ (dots), $60 \mathrm{~mm}$ (dashed-dotted line), from the bottom of the sample (thin solid line) and the excitation pulse (bold solid line) at a frequency of $300 \mathrm{kHz}$

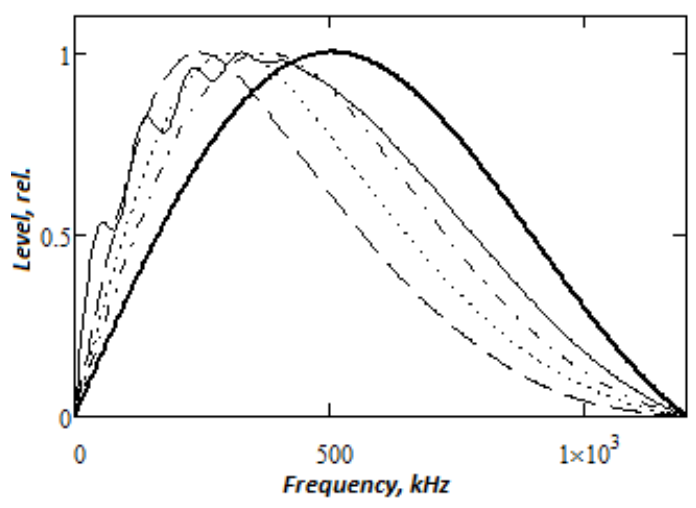

Figure 11. The amplitude-frequency characteristics of responses when reflected from defects at defect depths of $25 \mathrm{~mm}$ (dashed line), $40 \mathrm{~mm}$ (dots), $60 \mathrm{~mm}$ (dashed-dotted line), from the bottom of the sample (thin solid line) and the excitation pulse (thick solid line) at a frequency of $600 \mathrm{kHz}$

It follows from Figure 10 that, at a frequency of $300 \mathrm{kHz}$, the maxima of the frequency response of the responses relative to the frequency response of the initial excitation naturally shift to the low-frequency re- 
gion with a decrease in the depth of the defect. The nature of the response from the bottom of the sample becomes more complex.

And finally, in figure 11, at a frequency of $600 \mathrm{kHz}$, the manifestation of the displacement of the maxima of the frequency response increases significantly.

\section{Conclusion}

Based on the analysis of responses calculated using the two-dimensional ray model, the following conclusions can be drawn:

- the steepness of the impulse response when scanning along a sample with a defect increases with decreasing depth of the defect;

- the difference between the response duration and the excitation pulse duration at a given excitation frequency is an indicator of the depth of the location of defects;

- the degree of expansion of the response increases with increasing frequency of pulsed excitation;

- increasing the frequency of excitation increases the accuracy of estimating the depth of microdefects.

The work has been done with the financial support of the Russian Science Foundation, project No. 19-19-00178 (TPU - 5.2053.RNF.2019).

\section{References}

1 Mozgovoi N.I. The implication of acoustic method to control composite metal components / N.I. Mozgovoi, Ya.G. Mozgovaya, E.A.Pashkova // Metals treatment: technology, equipment, instruments. — 2015. — 3. — P. 68-71.

2 Blackshire J.L., Sathish S. Near-field ultrasonic scattering from surface-breaking cracks / J.L. Blackshire, S. Sathish // Applied Physics Letters. - 2002. — 80(18). - P. 3422-3444.

3 Seher, M. Numerical and experimental study of crack depth measurement in concrete using diffuse ultrasound / M. Seher, C.-W. In, J.-Y. Kim, K.E. Kurtis, L.J. Jacobs // Journal of Nondestructive Evaluation. — 2013. — 32. — P. 81-92.

4 Chitnalah A. Pulse echo method for nonlinear ultrasound parameter measurement / A. Chitnalah, D. Kourtiche, H. Jakjoud, M. Nadi // Electronic Journal Technical Acoustics. - 2007. - 13. - P. 138-145.

5 Bostrom A. Ultrasonic probe modeling and nondestructive crack detection / A. Bostrom, H. Wirdelius // Electronic Journal Technical Acoustics. — 1995. - 97. - P. 2836-2848.

6 Carpinteri A. Reliable onset time determination and source location of acoustic emissions in concrete structures / A. Carpinteri, J. Xu, G. Lacidogna, A. Manuello // Cement and Concrete Composites. — 2012. — 34(4). — P. 529-537.

7 Philippids T. Strength degradation due to fatigue -induced matrix cracking in FRP composites: An acoustic emission predictive model / T. Philippids, T. Assimakopoulou // Composites Science and Technology. 2008. — 68. — P. 15-16.

8 Shah A.A. Non-destructive evaluation of concrete in damaged and undamaged states / A.A. Shah, Y. Ribakov // Material Design. - 2009. - 30. - P. 3504-3511.

9 Wollbrandt M. The generation of high energies of bodies under destruction / M. Wollbrandt, Yu. Chrustalyov, E. Linke // DAN SSSR. - 1975. - 225(2). - P. 342-344.

10 Fursa T. The effect of filler grain size on effectiveness of method of mechanoelectric transformations in concrete / T. Fursa, V. Gordeev // Letters to the Journal of technical physics. - 2000. — 26(3). - P. 30-34.

11 Koktavy P. Experimental study of electromagnetic emission signals generated by crack generation in composite materials / P. Koktavy // Measurement Science \& Technology. - 2009. - 20(1).

12 Aydin, A., Prance, R.J. Prance, H., \& Harland, C.J. (2009). Observation of pressure stimulated voltages in rocks using an electric potential sensor. Applied Physics Letters, 95, 12, 124102-3.

13 Fursa T.V. Electromagnetic diagnostics of composite materials / T.V. Fursa, A.P. Surzhikov, N.N. Khorsov // Proceedings of the 8th China-Russia Symposium on New Materials and Technologies. (pp. 138-140). China, Guang-Zhou, 2005.

14 Крамер Г. Математические методы статистики. - М.: Мир, 1975. - 648 с.

15 Fursa T. Development of mechanoelectric method of estimation of defects coordinates for concrete samples / T. Fursa, K. Osipov, D. Dann // Control, Diagnostics. - 2012. — 11. - P. 66-69.

16 Khorsov P. The Application of Reverberation in Method of Mechanoelectrical Transformations for Estimation of StressStrain State in Solid Dielectric Matter / P. Khorsov, R. Laas, A. Surzhikov // Materials Science Forum 2019. — 970. — P. 47-54.

17 Van Damme B. Defect localization using the nonlinear impact modulation technique / B. Van Damme, K. Van Den Abeele // Emerging Technologies in Non Destructive Testing. - 2011. - 5. - 301-305.

18 Хорсов Н.Н. Математическая модель регистрации отклика при акустоэлектрическом преобразовании в образце с включением в виде двойного электрического слоя при точечном ударном возбуждении / Н.Н. Хорсов // Изв. вузов. Физика. — 2007. — T. 50, № 2. - C. 69-77.

19 Khaydarov B.K. Composite stratified-hardened containers for synthesis of diamond polycrystals of a type carbonado / B.K. Khaydarov, V.P. Makarov, K. Khaydarov // Bulletin of the University of Karaganda-Physics. 2018. — 4(92). - P. $101-106$. 
20 Demirli R. Ultrasonic flaw detection and imaging through reverberant layers via subspace analysis and projection / R. Demirli, M.G. Amin, X. Shen, Y.D. Zhang // Advances in Acoustics and Vibration. — 2012. — 957379. DOI:10.1155/2012/957379

21 Garnier V. Acoustic techniques for concrete evaluation: improvements, comparisons and consistency / V. Garnier, B. Piwakowski, O. Abraham, G. Villain, C. Payan, J.F. Chaix // Construction Building Materials. — 2013. - 43. - P. $598-614$.

22 Surzhikov A. A thermoanalysis of phase transformations and linear shrinkage kinetics of ceramics made from ultrafine plasmochemical $\mathrm{ZrO}_{2}(\mathrm{Y})-\mathrm{Al}_{2} \mathrm{O}_{3}$ powders / A. Surzhikov, T. Frangulyan, S. Ghyngazov // Journal of Thermal Analysis and Calorimetry. - 2014. - 115, 2. - P. 1439-1445.

23 Copuroglu, E., \& Mehmetoglu, T. (2019). Analytical evaluation of the Uehling potential using binomial expansion theorems /Copuroglu, E., \& Mehmetoglu, T.// Bulletin of the University of Karaganda-Physics, 3(95), 17-21.

24 Surzhikov A.P. Physics of magnetic phenomena: Investigation of electroconductivity of lithium pentaferrite / A.P. Surzhikov, T.S. Frangulyan, S.A. Ghyngazov, E.N. Lisenko, O.V. Galtseva // Russian Physics Journal. — 2006. — 49, 5. — P. 506-510. DOI: $10.1007 / \mathrm{s} 11182-006-0133-6$

\author{
Р.А. Лаас, П.Н. Хорсов, А.П. Суржиков, А.А. Беспалько, \\ А.С. Гынгазов, Д.Ж. Карабекова, А.К. Хасенов
}

\title{
Қатты диэлектриктерде макроақаулардың орнын табуға арналған механоэлектрлік түрлендіргіштер әдісінің екі өлшемді сәулелік математикалық моделі
}

\begin{abstract}
Қатты өткізбейтін үлгілердің көлденең күйін де, ақаудың тереңдігін де анықтау үшін механоэлектрлік қайта құру әдісін қолдануға болады. Бұл механоэлектрлік қайта құрылу көздеріндегі электромагниттік сәулелену құбылысына негізделген, мысалы, жарық құрылымдары, қуыстар және сынама құрылымының қоспалары. Көрсетілген әдісті қатты диэлектрлік материалдардың интеграцияланған кернеулі күйін бағалауда қолдануға болады. Сондай-ақ, әдіс үлгі көлеміндегі ақауларды анықтауға қабілетті, бірақ оның сенімді әдістемесін құру қажет. Сканерлеу процесін дұрыс жүргізу әдістемесін жасау үшін эксперименттік қондырғы құрастырылған. Жұмыста осы қондырғының сәулелік моделі ұсынылған. Модель қоздыру сигналының әртүрлі параметрлерін, ақаулардың орналасуы мен тереңдігін ескере отырып, жауап сигналының импульстік сипаттамаларын зерттеуге мүмкіндік береді. Модель нақты үлгінің өлшемдерін камтиды. 100 кГц, 300 және 600 кГц жиіліктері бар бір кезеңді козу толқындарының жауап сигналдары үшін импульстік сипаттамалар алынған. Қозу жиілігін арттыру арқылы макроақаулардың тереңдігін бағалау дәлдігін жоғарылатуға болатыны көрсетілген. Сигналдың уақытттық сипаттамалары ең ақпаратты болып табылады.
\end{abstract}

Кілm сөздер: механоэлектрлік түрлену, акустикалық бақылау, бұзбай бақылау, сәулелікматематикалық модель, қатты диэлектрлік құрылымдар, дефектоскопия, жауап сигналы, қозу толқыны.

\section{Р.А. Лаас, П.Н. Хорсов, А.П. Суржиков, А.А. Беспалько, А.С. Гынгазов, Д.Ж. Карабекова, А.К. Хасенов \\ Двумерная лучевая математическая модель метода механоэлектрических преобразований для поиска местоположения макродефектов в твердых диэлектриках}

\begin{abstract}
Метод механоэлектрических преобразований может быть применен для определения как горизонтального положения, так и глубины дефекта в твердых непроводящих образцах. Он основан на явлении электромагнитного излучения в источниках механоэлектрических преобразований, таких как трещины, пустоты и примеси структуры образца. Показано, что указанный метод может быть использован для оценки интегрального напряженно-деформированного состояния твердых диэлектрических материалов. Кроме того, способен обнаруживать дефекты в объеме образца, однако необходимо разработать надежную методологию. Для разработки методологии правильного процесса сканирования была создана экспериментальная установка. Эта работа представляет лучевую модель этой установки. Модель позволяет исследовать импульсные характеристики ответного сигнала с учетом различных параметров сигнала возбуждения, местоположения дефектов и глубины. Включает в себя размеры реального образца. Получены импульсные характеристики для ответных сигналов однопериодических волн возбуждения с частотами 100, 300 и 600 кГц. Показано, что увеличение частоты возбуждения повышает точность оценки глубины макродефектов. Временные характеристики сигнала являются наиболее информативными.
\end{abstract}


Ключевые слова: механоэлектрические преобразования, акустический контроль, неразрушающий контроль, лучевая математическая модель, дефектоскопия, возбуждающий сигнал, сигнал отклика, твердые диэлектрические структуры.

\section{References}

1 Mozgovoi, N.I., Mozgovaya, Ya.G., \& Pashkova, E.A. (2015). The implication of acoustic method to control composite metal components. Metals treatment: technology, equipment, instruments, 3, 68-71.

2 Blackshire, J.L., \& Sathish, S. (2002). Near-field ultrasonic scattering from surface-breaking cracks. Applied Physics Letters, 80(18), 3422-3444.

3 Seher, M., In, C.-W., Kim, J.-Y., Kurtis, K.E., \& Jacobs, L.J. (2013). Numerical and experimental study of crack depth measurement in concrete using diffuse ultrasound. Journal of Nondestructive Evaluation, 32, 81-92.

4 Chitnalah, A., Kourtiche, D., Jakjoud, H., \& Nadi, M. (2007). Pulse echo method for nonlinear ultrasound parameter measurement. Electronic Journal Technical Acoustics, 13, 138-145.

5 Bostrom, A., \& Wirdelius, H. (1995). Ultrasonic probe modeling and nondestructive crack detection. Electronic Journal Technical Acoustics. 97, 2836-2848.

6 Carpinteri, A., Xu, J., Lacidogna, G., \& Manuello, A. (2012), Reliable onset time determination and source location of acoustic emissions in concrete structures. Cement and Concrete Composites, 34(4), 529-537.

7 Philippids, T., \& Assimakopoulou, T. (2008). Strength degradation due to fatigue -induced matrix cracking in FRP composites: An acoustic emission predictive model. Composites Science and Technology, 68, 15-16.

8 Shah, A.A., \& Ribakov, Y. (2009). Non-destructive evaluation of concrete in damaged and undamaged states. Material Design, 30, 3504-3511.

9 Wollbrandt, M., Chrustalyov, Yu., \& Linke, E. (1975). The generation of high energies of bodies under destruction. DAN SSSR, 225(2), 342-344.

10 Fursa, T., \& Gordeev, V. (2000). The effect of filler grain size on effectiveness of method of mechanoelectric transformations in concrete. Letters to the Journal of technical physics, 26(3), 30-34.

11 Koktavy, P. (2009). Experimental study of electromagnetic emission signals generated by crack generation in composite materials. Measurement Science \& Technology 20(1).

12 Aydin, A., Prance, R.J. Prance, H., \& Harland, C.J. (2009). Observation of pressure stimulated voltages in rocks using an electric potential sensor. Applied Physics Letters, 95, 12, 124102-3.

13 Fursa, T.V., Surzhikov, A.P., \& Khorsov, N.N. (2005). Electromagnetic diagnostics of composite materials. Proceedings of the 8th China-Russia Symposium on New Materials and Technologies. (pp. 138-140). China, Guang-Zhou.

14 Kramer, G. (1975). Matematicheskie metody statistiki [Methods of mathematical Statistics]. Moscow: Mir [in Russian].

15 Fursa, T., Osipov, K., Dann, D. (2012). Development of mechanoelectric method of estimation of defects coordinates for concrete samples, Control, Diagnostics, 11, 66-69.

16 Khorsov, P., Laas, R., \& Surzhikov A. (2019). The Application of Reverberation in Method of Mechanoelectrical Transformations for Estimation of Stress-Strain State in Solid Dielectric Matter, Materials Science Forum 970, 47-54.

17 Van Damme B., \& Van Den Abeele, K. (2011.) Defect localization using the nonlinear impact modulation technique, Emerging Technologies in Non Destructive Testing, 5, 301-305.

18 Khorsov, N.N. (2007). Matematicheskaia model rehistratsii otklika pri akustoelektricheskom preobrazovanii v obraztse s vkliucheniem $v$ vide dvoinoho elektricheskoho sloia pri tochechnom udarnom vozbuzhdenii [Mathematical model of response registration in acoustoelectric transformation in a sample with inclusion in the form of a double electric layer under point shock excitation]. Izvestiia vuzov. Fizika - University news. Physics, Vol. 50, 2, 69-77 [in Russian].

19 Khaydarov, B. K., Makarov, V. P., \& Khaydarov, K. (2018). Composite stratified-hardened containers for synthesis of diamond polycrystals of a type carbonado, Bulletin of the University of Karaganda-Physics, 4(92), 101-106.

20 Demirli, R., Amin, M.G., Shen, X., \& Zhang Y.D. (2012). Ultrasonic flaw detection and imaging through reverberant layers via subspace analysis and projection. Advances in Acoustics and Vibration, 957379. doi:10.1155/2012/957379

21 Garnier, V., Piwakowski, B., Abraham, O., Villain, G., Payan, C. \& Chaix, J.F. (2013). Acoustic techniques for concrete evaluation: improvements, comparisons and consistency. Construction Building Materials, 43,) 598-614.

22 Surzhikov, A., Frangulyan, T., Ghyngazov, S. (2014). A thermoanalysis of phase transformations and linear shrinkage kinetics of ceramics made from ultrafine plasmochemical $\mathrm{ZrO}_{2}(\mathrm{Y})-\mathrm{Al}_{2} \mathrm{O}_{3}$ powders. Journal of Thermal Analysis and Calorimetry, 115, 2, $1439-1445$.

23 Copuroglu, E., \& Mehmetoglu, T. (2019). Analytical evaluation of the Uehling potential using binomial expansion theorems. Bulletin of the University of Karaganda-Physics, 3(95), 17-21.

24 Surzhikov, A.P., Frangulyan, T.S., Ghyngazov, S.A., Lisenko, E.N., Galtseva, O.V. (2006). Physics of magnetic phenomena: Investigation of electroconductivity of lithium pentaferrite. Russian Physics Journal, 49, 5, 506-510. doi: 10.1007/s11182-006$0133-6$ 